\title{
An evolutionary approach to air transport: market, technology and institutional co-evolution
}

\author{
Pere Suau-Sanchez \\ Cranfield University. Department of Air Transport \\ p.suausanchez@cranfield.ac.uk
}

\section{Montserrat Pallares-Barbera}

Universitat Autònoma de Barcelona. Departament de Geografia

montserrat.pallares@uab.cat

Received: September 2012

Accepted: December 2012

\begin{abstract}
This paper covers the development dynamics of the air transportation industry. Having the evolutionary economic geography as the frame of reference, we analyze the co-evolution of the market (selective environment), the aeronautics knowledge and equipment (technology) and the air transportation institutional policy (policy). The stress is on those factors affecting network formation and tie selection. The results of this investigation add to the limited empirical research on the evolution of transport network systems. We found that air transport shows a path dependency; although at the same time has a strong level of uncertainty due to exogenous factors. Also, the co-evolution between the selective market environment, technology and institutional decisions has been verified. The latter happen to be key, as the evolution of air transportation can only be understood in the context of a mixed regulatory environment that provides different levels of freedom for network formation.
\end{abstract}

Keywords: air transport; economic geography; network; path dependency.

Resum. Un enfocament evolucionista del transport aeri: coevolució del mercat, la tecnologia $i$ les institucions

Aquest article se centra en les dinàmiques existents a la indústria del transport aeri. Utilitzant com a marc teòric la geografia econòmica evolucionista, analitzem la coevolució entre el mercat (ambient selectiu), el coneixement i l'equipament aeronàutic (tecnologia) i les polítiques públiques en transport aeri (institucions). El focus de la nostra anàlisi se situa en els factors que afecten la formació de la xarxa i la selecció d'enllaços. Els resultats mostren que el transport aeri té una alta dependència de la trajectòria anterior, tot i que al mateix temps demostra una alta incertesa a causa de factors externs. També s'ha confirmat l'existència de processos de coevolució entre l'ambient selectiu del mercat, la tecnologia 
i les decisions institucionals. Aquestes últimes demostren ser claus, ja que l'evolució del transport aeri només es pot entendre en el context d'un ambient de regulació mixta que proporciona diferents nivells de llibertat per a la formació de xarxes.

Paraules clau: transport aeri; geografia econòmica; xarxes; dependència de la trajectòria prèvia.

Resumen. Un enfoque evolucionista del transporte aéreo: coevolución del mercado, la tecnología y las instituciones

Este artículo se centra en las dinámicas existentes en la industria del transporte aéreo. Utilizando como marco teórico la geografía económica evolucionista, analizamos la coevolución entre el mercado (ambiente selectivo), el conocimiento y el equipo aeronáutico (tecnología) y las políticas públicas de transporte aéreo (instituciones). El foco de nuestro análisis se centra en los factores que afectan a la formación de la red y la selección de enlaces. Los resultados muestran que el transporte aéreo tiene una alta dependencia de la trayectoria anterior, aunque al mismo tiempo demuestra una alta incertidumbre a causa de factores externos. También se ha confirmado la existencia de procesos de coevolución entre el ambiente selectivo del mercado, la tecnología y las decisiones institucionales. Estas últimas demuestran ser claves, ya que la evolución del transporte aéreo solo puede entenderse en el contexto de un ambiente de regulación mixta que proporciona diferentes niveles de libertad para la formación de redes.

Palabras clave: transporte aéreo; geografía económica; redes; dependencia de la trayectoria anterior.

Résumé. Une approche évolutionniste au transport aérien : coévolution du marché, de la technologie et des institutions

Cet article met l'accent sur la dynamique de développement de l'industrie du transport aérien. Avec la géographie économique évolutionniste comme cadre de référence, nous analysons la coévolution du marché (milieu sélectif), avec la connaissance et l'équipement aéronautique (technologie) et la politique institutionnel des transports aériens (politique). L'accent est mis sur les facteurs qui influent sur la formation des réseaux et la sélection des liaisons aériennes. Les résultats de cette étude ont permis d'améliorer la recherche empirique sur l'évolution des systèmes de réseau de transport. Nous avons constaté que le transport aérien montre une dépendance au sentier, bien que dans le même temps a un fort niveau d'incertitude due à des facteurs exogènes. De plus, nous avons vérifiée la coévolution entre l'environnement sélective du marché, la technologie et les décisions institutionnelles. Ces derniers sont des décisions clés, car l'évolution du transport aérienne peut être comprise que dans le contexte d'un environnement mixte réglementaire qui offre différents niveaux de liberté pour la formation des réseaux.

Mots clé: transport aérien; géographie économique; réseaux; dépendance au sentier.

\section{Summary}

1. Introduction 4. Conclusions

2. The evolutionary approach Acknowledgments in economic geography References

3. Air transportation co-evolution 


\section{Introduction}

Air transportation has been a common theme in economic geography literature in relation to the analysis of airline routes and flows, the study of international supply chains, location analysis, the impact of airport noise on residential property values and environmental issues (e.g., Witlox et al. 2007; Burghouwt, 2007; Leinbach and Bowen, 2004; Seguí and Martínez, 2004; Graham, 1995; Espey and Lopez, 2000; Gámir and Ramos, 2002; Tomkins et al., 1998; Stutz, 1986; Karaska and Bramhall, 1960). Meanwhile, economic geography has moved away from traditional economic analysis and has become a more interdisciplinary speciality adopting insights from social, cultural and political sciences (Boschma and Frenken, 2006). A relatively recent development in economic geography is the evolutionary approach, which combines different kinds of quantitative and qualitative methodologies, all based on an evolutionary approach (Boschma and Frenken, 2007), which borrows the Darwinian concepts of selection, retention (heredity) and variety in order to apply them to social sciences. This approach overcomes static theories and focuses on innovation and technology as elements of self-transformation.

This paper is a first approach to the discussion of the co-evolution dynamics in the air transport industry. The complexity of this industry and the constraints on the capacity of airports to cope with future growth are the central elements considered in discussing the limits of network formation. We have identified the selective environment (the liberalised market and the context of insufficient capacity), technology (engineering and aeronautics technology) and policies (air transportation regulations and other policies) as three co-evolving elements. In a context of increasing demand and environmental constrains, the issue is how the co-evolution of these three factors has influenced the path for coping with the level of network formation demanded by society.

\section{The evolutionary approach in economic geography}

There is a relatively wide range of evolutionary approaches in economic geography (see Economic Geography 85(2) and Boschma and Frenken (2011) for a debate on the directions of the evolutionary project in economic geography) and there is thus far no general agreement regarding a definition of evolutionary economic geography (Martin and Sunley, 2006; Essletzbichler and Rigby, 2007; Glückler, 2007). Boschma and Martin argue that it could roughly be said that "the basic concern of evolutionary economic geography is with the processes by which the economic landscape -the spatial organization of economic production, distribution and consumption- is transformed over time" (Boschma and Martin, 2007: 539). More recently, Boschma and Frenken (2011: 295) state that "Evolutionary Economic Geography explains the spatial evolution of firms, industries, networks, cities and regions from elementary processes of entry, growth, decline and exit of firms, and their 
locational behaviour." According to Boschma and Martin (2007), theories of evolutionary economic geography have to fulfil three requirements: they must be dynamic (referring to concepts such as emergence, convergence, divergence and other irregular patterns, rooted in historical times), they must deal with irreversible processes, and must embrace the generation of novelty (the creative capacity of economic agents) as the main source of self-transformation. These elements are closely related to evolutionary biology and Darwinian theory (variety, selection and retention/heredity), which can be considered as a 'metatheoretical framework' for understanding social systems (Hodgson, 2009). In fact, evolutionary thinking has become increasingly significant for social sciences and economics (Nelson and Winter, 1982; Dosi and Nelson, 1994; Boschma et al., 2002; Bertolini, 2007). Individual decisions eventually accumulate into development processes that are path dependent and unpredictable, and such complexity bounds the rationality of those actors involved (Bertolini, 2007), although the randomness of the evolutionary process does not replace human agency (Hodgson, 2009).

An evolutionary perspective of economic geography could be considered a third way in economic geography, openly combining the new (neoclassical) economic geography and the institutional approach to economic geography -two perspectives that have developed independently from each other (Boschma and Frenken, 2007). Other approaches, such as the firm theory and political economic geography, are also influencing the evolutionary approach. The evolutionary approach agrees with the usefulness of formal modelling, which requires some degree of abstraction from local contexts, and with the institutional approach, in its assumption of bounded rationality (Gigerenzer and Selten, 2002) and its emphasis on the contextuality of human decisionmaking (Boschma and Frenken, 2006; Storper, 2009). This third approach views the economy as an evolutionary process that unfolds in space and time (Martin, 2009). It focuses on the path dependent dynamics underlying uneven economic development in space -especially firm dynamics, and the rise and fall of technologies, networks and institutions in different contexts (Martin and Sunley, 2006) (Table 1).

Table 1. A comparison of three approaches in economic geography

\begin{tabular}{|c|c|c|c|}
\hline Key issues & Neoclassical & Institutional & Evolutionary \\
\hline \multirow[t]{2}{*}{ Methodology } & Deductive & Inductive & Both \\
\hline & Formal modelling & Appreciative theorising & Both \\
\hline \multirow[t]{2}{*}{ Key assumptions } & Optimising agent & Rule-following agent & Satisfying agent \\
\hline & A-contextual & Contextual (macro) & Contextual (micro) \\
\hline \multirow{2}{*}{$\begin{array}{l}\text { Conceptualisation } \\
\text { of time }\end{array}$} & Equilibrium analysis & Static analysis & Out-of-equilibrium analysis \\
\hline & Micro-to-macro & Macro-to-Micro & Recursive \\
\hline \multirow[t]{2}{*}{ Geography } & Neutral space & Real place & Neutral space à real place \\
\hline & Transport cost & Place dependence & Path dependence \\
\hline
\end{tabular}

Source: Boschma and Frenken (2006). 


\subsection{Evolutionary models of network formation}

Networks (transport technology and information and computer technology) act as vehicles for knowledge creation and diffusion and are implicit in any account of the geography of economic relations (Castells, 1996; Cowan and Jonard, 2003). They represent the architecture through which productive resources, social values and economic interests circulate. Network evolution is understood to be an entry process for new nodes (Boschma and Frenken, 2006) and a destructive process for existing nodes. Considering airports as nodes in airline networks, it is important to examine the geographical network trajectory concept formulated by Glücker (2007). "The network trajectory (Kilduff and Tsai, 2003) is an appropriate concept in the analysis of network evolution which combines the notions of evolution, network and geography: it describes a geographically and historically specific development path of a network in which the formation and dissolution of ties in earlier stages generates cumulative propensities for the formation and dissolution of ties in the future and in which the mechanisms of path-disruption and variation are endogenous" (Glücker, 2007: 622). In this regard, Glücker (2007) considers four elements to be defined. Firstly, selection may be a function of exogenous change with respect to the degree of adaptation of relationships, but also a function of endogenous incentives and strategies to choose and change relations by both parties involved in a relationship. Secondly, a theory of network evolution has to theorize on the emergence and disappearance of ties and nodes. Thirdly, interaction is costly and as such is a scarce resource. Fourthly, from a utility perspective, tie selection may be conceived as the competitive allocation of scarce relationships where the commitment devoted to one relationship involves opportunity costs for each unmade contact; thus tie selection is a competitive process that depends on exogenous changes as well as endogenous dynamics.

In the light of the above, networks can be understood as complex systems. Since complexity bounds the rationality of the players in a real economic situation, co-evolution between the market and individual firms can take place. In spite of the interest in co-evolution processes in network evolution, there has been limited empirical research on transportation network systems. Bertolini (2007) establishes an analogy with urban transportation systems in which he suggests the existence of co-evolution between policies (urban transportation and land-use policies) and the selective environment (the socio-demographic and economic context). As mentioned in the introduction, this chapter establishes a similar analogy to Bertolini's, but for the case of air transportation systems it is argued that there exists a co-evolution between the selective environment, technology and policies.

\section{Air transportation co-evolution}

\subsection{Selective environment}

Air transportation is an engine for shaping the economic landscape of regions. For example, a 10 per cent increase in the supply of intercontinental flights 
leads to around a 4 per cent increase in the number of big companies having their headquarters located in the corresponding urban area (Bel and Fageda, 2008). A supply of quality airport services can enhance the productivity of companies by facilitating access to providers and clients (Bel and Fageda, 2007). Air cargo services are also an important aspect of the region-specific assets with which needs of trans-local firms are coupled in global production networks. Regional development has thus become dependent, to some degree, on the effectiveness of the interaction of producing services in order to support production demand (Leinbach and Bowen, 2004; Wood, 2002).

Air transport travel is a rapidly-growing market. According to Airports Council International (ACI), total worldwide passenger traffic reached an all time high in 2006, moving almost 4.4 billion passengers (ACI, 2007). Longterm traffic forecasts indicate that by 2025 the number of passengers will double and will exceed nine billion passengers (ACI, 2007). If current capacity levels are not drastically increased, the European Commission estimates that by 2025 , over 60 European airports will be heavily congested and the top 20 airports will be saturated at least 8-10 hours a day. Such congestion is likely to have a severe impact on airlines' ability to maintain their schedules, especially at hub airports (EC, 2006a). ${ }^{1}$

Limited airport capacity is a constraint not only on the regional and local economy itself, but also on the global economy (i.e. delays, connectivity levels, mobility opportunities, etc.) and the global environmental agenda (i.e. extra fuel consumed in landing queuing, etc.).

As in any complex system, there are several elements affecting airport capacity and generating an environment of scarcity and selectivity. Constraints in airport capacity create network variations by fostering the competitive allocation of scarce relationships in which selection becomes a driving force for change. Some of these elements can be explained by exogenous reasons, while others are endogenous factors that are intrinsic elements that structure the current air transportation dynamics. Endogenous selection is revealed, for example, by airport alliances and by the behaviour of airlines. Exogenous selection is, for instance, influenced by the environment of the air transport network composed of various stakeholders that try to manipulate the network structure in their favour, and institutions that control the organization of the network. Also, heredity and path dependence are elements for maintaining network structures, since they create static ties in the network. For example, long-haul network structures are still highly defined by past choices in bilateral air service agreements between countries. Let us see these factors in more detail.

Some elements favouring heavy increases in passenger and cargo demand can be classified as exogenous factors of the industry, creating selectivity by putting pressure on existing capacity. Air transport is a cyclical industry, which

1. It should be noted here that airport capacity issues are concentrated in the European and North American markets. In other markets, especially in the Asia-Pacific market, airport capacity is still growing and does not represent a constraint. 


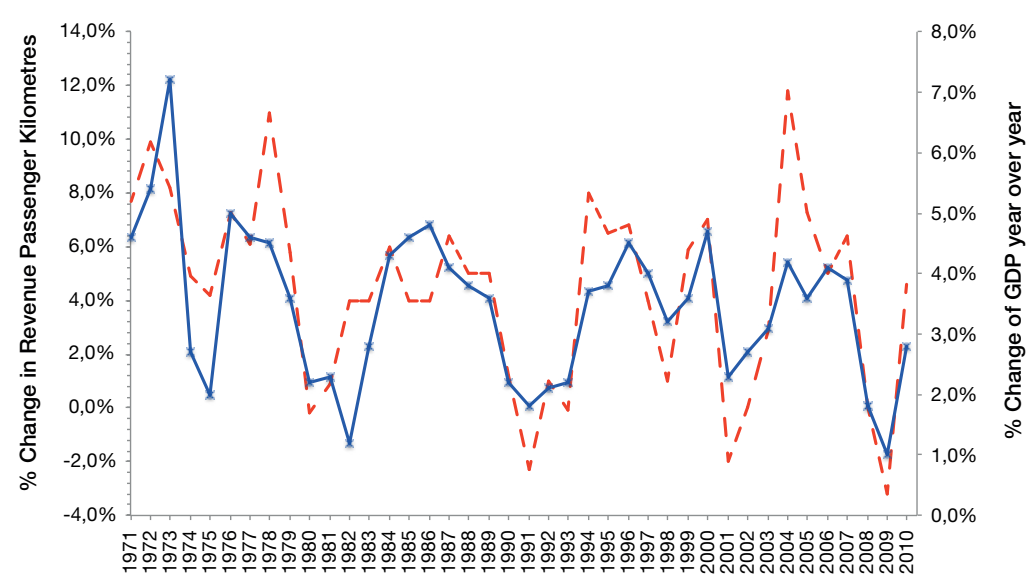

- - - World Scheduled airline RPKs — — World GDP grouth

Figure 1. Co-evolution of world GDP growth and Revenue Passenger Kilometre (RPK).

Source: O'Connell, 2012.

is heavily affected by the evolution of the Gross Domestic Product (GDP) (IATA, 2008), and this creates important variations in the demand for air services (Figure 1). Doganis (2002) observes that each cycle lasts about eight to ten years and asserts that the industry is inherently unstable. Many of these cycles are not only affected by the GDP, but also by world crises and by other external developments: the Arab-Israeli war in 1973 that was followed by the 1973 oil crisis, the 1979 oil crisis, the rise in oil prices in 1990 and the Gulf War that triggered massive injections of capital to many airlines to enable them to survive, the production quotas imposed by OPEC in 1999 that made the price of oil rise again, the 9/11 attacks and the SARS (Severe Acute Respiratory Syndrome) outbreak which converted the 1999-2000 air transport crisis into a disaster in 2001, the 2008 financial crisis and the 2009 flu pandemic. At the end of the seventies, other external, institutionally-based factors in the US were stimulating a less regulated environment and driving the industry towards liberalization. In a liberalized environment, market selection became stronger. The elimination of many air-service restrictions and unfair competitive practices permitted the expansion of scheduled services and the reduction of fares, and therefore the demand increased.

There are also endogenous factors that play a role in the formation of an environment featured by a high level of selection. Airport capacity is composed of several elements (Suau-Sanchez et al., 2011). If one of these variables is not performing well, the whole system becomes affected. Because of this, in practice, potential airport capacity is hardly ever achieved. The main elements defining airport capacity are technical features of the infrastructure, such as runways, terminal facilities or the apron. Other elements, such as the capacity 
provided by the Air Traffic Management (ATM), are key issues, although they are not always fully dependant on the airport itself, but rather on the regional context. There is a group of factors related to environmental concerns that also affect the overall airport capacity: noise from aircraft and ground traffic, airside and landside emissions (especially $\mathrm{CO}_{2}, \mathrm{NO}_{\mathrm{X}}$ and fine particles), visual impacts on landscape, etc. (Graham and Guyer, 1999; Upham et al. 2003; Goetz and Graham, 2004; Suau-Sanchez, et al. 2011). For instance, emission limits (EU Directive 2008/50/EC. See EC 2008) and noise restrictions (EU Directive 2002/30/EC and Directive 2006/93/EC. See EC, 2002 and 2006b) have a tremendous effect on the operational capacity of an airport. These environmental limits reveal an institutional concern for the internalization of the external costs created by the aviation activity.

In practical terms, in many airports, environmental considerations result in a more selective use of airport capacity. This means that airport managers are starting to ask themselves what kind of traffic (connection traffic, low-cost operations, charter flights, etc.) the airport should accommodate. Recalling Glücker (2007), tie selection may be conceived as the competitive allocation of scarce relationships where the commitment devoted to one relationship involves opportunity costs for each unmade contact.

\subsection{The role of technology}

According to Nelson (2005), the evolution of technology displays path dependencies with early developments that seem to shape the path of further technological development, and in particular to turn it and take it down a certain route when another might have been possible. In aviation, innovation has centred on the development of the jet engine for civil use, first in turboprop form and later as pure jet. Successive developments of the jet engine have constantly improved its efficiency and propulsion power. Improvements in airframe design and increases in aircraft size combined with increases in speed led to major improvements in aircraft productivity (Doganis, 2002).

As Nelson (2005) argues, the rate and direction of technological advance is, to a considerable extent, shaped by the activities of business firms, which are the repositories of extant technological capabilities. In the case of aviation, military research is the main source of technological innovation. In a second phase, aircraft manufacturers and engineering firms drive technological progress and adaptation for civil applications. Hence, firstly, institutions and public investment shape technological advance, and secondly, business companies, which at the same time have strong links with public institutions, push technological advance. $^{2}$

2. Tiffin and Kissling (2007) stress that transport cannot happen without advances in communication technology. The latter moves information and the former atoms. According to them, transport is made possible by the interaction of transport and communication networks. Transport only advances if there is technological improvement in both elements. 
Technology has created new environments in which competition and selectivity is more aggressive. One example is the appearance of low-cost carriers. These have become a major threat for the former flagship airlines, which have had to adapt to a new competitive environment. Low-cost carriers emerged for two reasons: firstly, because the regulatory environment allowed it and, secondly, because the necessary technology was available. Most low-cost carriers operate aircraft from the newest series of Airbus A320 and Boeing B737. These aircrafts are designed for short-haul services, are relatively small -which allows higher load factors- and are highly fuel-efficient. ${ }^{3}$

On the other hand, technology has been an element that has provided more capacity for airports and airspace, thereby creating a lower level of competition and selectivity. One good example is the Single European Sky (Button and McDougall, 2006). The EU does not have a single unified airspace, and this means that each national air navigation centre controls flights passing through each member's airspace. This makes coordinating the flights crossing different air navigation centres a complex task, which complicates the allocation of new flights. At the end of 2004 the EU decided to launch the SESAR project, which should develop the technology that will allow implementing the Single European Sky and will provide sufficient airspace capacity for the coming 30 years.

\subsection{Institutional reactions}

Although air transportation has gone through several waves of deregulation and liberalization, it has been one of the most highly regulated industries. Doganis (2002) classifies the regulations into the following categories: (a) regulations dealing with the airworthiness of the aircraft in terms of design, production standards and performance, (b) regulations dealing with the supervision of maintenance and overhaul work and the qualifications of engineers, (c) regulations governing the number of flight and cabin crew, their training and licensing, their duties and functions on board and their work loads and schedules, (d) regulations dealing with the way in which aircraft are operated and (e) regulations and standards dealing with aviation infrastructure. In addition to these particular regulations, on a global level air transportation remains a

3. While today it might be considered that the A320 and the A737 are not the newest technology available, at the moment of their appearance they represented a considerable improvement in terms of efficiency compared to the existing aircraft technology used for short-haul services. This allowed airlines to have a lower cost base and contribute to lowering the price of the ticked for the consumer. In this regard, the improvement on aircraft technology has always been a key element in the configuration of airline networks and the definition of infrastructure needs. One of the earliest best examples is the shift from propeller planes to jet aircraft, which had a revolutionary impact on trip distance and airport size requirements. In a similar way, the new B787 Dreamliner will allow connecting very thin markets that were not possible to connect non-stop with jumbo jets, such as the B747 or the A380, which are designed for connecting hub-to-hub markets and have greatest requirements in terms of runway size than the B787 Dreamliner. 
national issue. The states established the basis for today's air transportation in two conventions. The first of these was the Paris Convention, signed in 1919. It was accepted that states have sovereign rights over the airspace around their territory, and with this, direct government intervention in air transportation became inevitable. Secondly, in 1944 representatives from fifty-two member states met in Chicago and reached an agreement for the exchange of traffic rights (also known as freedoms of the air), the control of fares and freight tariffs, and the control of flight frequencies and capacity. In time, the exchange of traffic rights became a matter for bilateral service agreements between states, tariffs came to be regulated by the International Air Transport Association (IATA) and the control of frequencies became a matter for inter-airline agreements. Be that as it may, these three aspects regulate the entry of firms into the market, the degree of pricing freedom and the nature of controls on production.

The most important purpose of bilateral agreements has been the control of market access (airports to be served and traffic rights) and of market entry (which airlines can be designated to use the traffic rights granted). Bilateral agreements remain the fundamental core of the regulatory regime. Yet, such a regime coexists with a more 'open skies' regime. In 1978, the US Airline Deregulation Act was signed into law. By 1985, the act had brought an end to all controls over US domestic routes and fares. In addition, between 1977 and 1985 the US administration also renegotiated most of the bilateral agreements that they had with other countries. The first real open market bilateral agreement was the US-Netherlands bilateral agreement signed in 1978, which set the trend for subsequent US bilateral agreements. In Europe, air transport deregulation has developed in three steps known as the first (1987), second (1990) and third (1993) deregulation packages. However, only since 1997 has there been a full open skies regime for air services within the European Union. The trend towards liberalization continues, as an increasing number of bilateral air service agreements are renegotiated at the EU level. A recent accomplishment (2008) includes the first phase of an Open Sky Agreement between the EU and the US, giving carriers registered in the EU or the US the right to operate services between any points in the EU and US. There is a large body of literature showing the impacts of de-regulation on the allocation of airport seat capacity and airline network configurations (see, for example, Reynolds-Feighan (1998, 2001, 2007a, 2007b), Goetz and Graham (2004), Burghouwt (2007), Suau-Sanchez and Burghouwt (2011)).

This general shift towards liberalisation is also impacting airports. Currently, there is a mix of airport management models (Table 2). Depending on the country, airport management is individual for each airport or centralized. In general, individual airport management is predominant in most countries, regardless of ownership (public or private). Probably, what is more relevant is whether management is individual or central, since it has direct impact on who decides for airport investments, slot allocation, airport marketing and other significant issues. 
Air transportation can only be understood in the context of this mixed regulatory environment, which provides different levels of freedom for network formation in different regions. There is a constellation of institutions that add to the complex international regulatory regime. We can find airline associations (e.g., the International Air Transport Association), manufacturers associations (e.g., the Air Transport Action Group), airport associations (e.g., the Airports Council International), regions associations (e.g., the Airports

Table 2. Airport management models in Europe

\begin{tabular}{|c|c|c|}
\hline Country & Airport Management & Ownership \\
\hline United Kingdom & Individual & Private, regional government \\
\hline Germany & Individual & Private, central and regional governments \\
\hline Spain & $\begin{array}{l}\text { In process of partial } \\
\text { individualization }\end{array}$ & In process of partial privatization \\
\hline France & Individual & $\begin{array}{l}\text { Central government (Paris), chambers of commerce } \\
\text { (rest of airports) }\end{array}$ \\
\hline Italy & Individual & Private, regional government \\
\hline The Netherlands & Individual & Private, central, regional and local governments \\
\hline Greece & Partially individual & Private (Athens), central government (rest of airports) \\
\hline Sweden & Centralized & Central government \\
\hline Ireland & Individual & Central government \\
\hline Denmark & Individual & Private, central government \\
\hline Portugal & $\begin{array}{l}\text { In process } \\
\text { of individualization }\end{array}$ & In process of privatization \\
\hline Austria & Individual & Private, central government \\
\hline Belgium & Individual & Private, regional government \\
\hline Finland & Centralized & Central government \\
\hline Luxemburg & Individual & Central government \\
\hline Czech Republic & Centralized & Central government \\
\hline Poland & $\begin{array}{l}\text { In process } \\
\text { of individualization }\end{array}$ & Central Government \\
\hline Hungary & Individual & $\begin{array}{l}\text { Private (Budapest), central government } \\
\text { (rest of airports) }\end{array}$ \\
\hline Cyprus & Centralized & Central government \\
\hline Malta & Individual & Private (Malta), central government (rest of airports) \\
\hline Slovakia & Individual & $\begin{array}{l}\text { Private (Bratislava), central government } \\
\text { (rest of airports) }\end{array}$ \\
\hline Latvia & Centralized & Central government \\
\hline Slovenia & Individual & $\begin{array}{l}\text { Private (Ljubljana), central government } \\
\text { (rest of airports) }\end{array}$ \\
\hline Lithuania & Centralized & Central government \\
\hline Estonia & Centralized & Central government \\
\hline
\end{tabular}

Source: adapted from Bel and Fageda, 2007. 
Regions Conference), state associations (e.g., the International Civil Aviation Organization), among others.

Institutions sometimes act in both directions. While in some cases they lobby for their interests, in others they work towards opening up the market, which can promote a higher level of network formation. For example and as stated above, low-cost carriers exist because the regulatory regime initially allowed it. Yet, institutions not only raise the network formation by opening and deregulating the market. The aforementioned technological project SESAR, which will bring more air space capacity, is promoted by the EU. The US is going in the same direction with the NextGen project. At a lower scale, land-use policies by municipalities located in the vicinity of airports can have important effects on the operational performance of airports and therefore on capacity.

\section{Conclusions}

Air transport is influenced by path dependency while, at the same time, it suffers from a high level of uncertainty due to exogenous factors such as economic cycles. In fact, De Neufville and Odoni (2003) state that forecasts are always wrong in air transportation, which makes expansions of airport infrastructure very uncertain investments. Not only are exogenous elements playing a role in creating an uncertain environment, but also deregulation and liberalization -in the form of a long succession of decisions taken by institutions related to the air transportation industry- is a path that leads to increasing variation and volatility. Overall, the fluctuations of traffic in a deregulated environment are much greater than in a regulated environment. Deregulation also leads to significant changes in the structure of the airline industry, and increasing competition has normally led to the disappearance of airlines through mergers or bankruptcies (De Neufville and Odoni, 2003).

We have also observed the presence of co-evolution between the selective market environment, technology and institutional decisions. The decisions taken by national or international institutions appear to have clear implications for the path and evolution of the market and the density of network formation. At the same time, institutions have also been dictating the direction of technological advance, especially through intermediate bodies such as the air force and military research. In more recent times, private firms have to some extent increased their role in contributing to technological advance in aviation, especially in the fields of environment and fuel-efficiency, although this technological research is very often commissioned by public institutions.

Further research should examine the implications of this complex environment and the co-evolution between the various variables in the decision-making process. Does the decision-making process include variability and uncertainty variables? Is the co-evolution of a selective environment, technology and policies also really taken into account when deciding future infrastructure enlargements? 


\section{Acknowledgments}

This research was supported by the Spanish Ministry of Science and Innovation (Grants CSO2010-17178 and CSO2011-13651-E) and the Catalan Agency for the management of University and Research Grants (Grants 2009SGR0106 and AC065723).

\section{References}

ACI (2007). «Statistics: Top 10 World Airports. ACI Information brief». Available online at: www.aci.aero [accessed: 14 June 2010].

BeL, G. and FageDA, X. (2007). Aeroports i poder. Barcelona: Edicions 62.

- (2008). «Getting there fast: Globalization, intercontinental flights and location of headquarters». Journal of Economic Geography, 8 (4), 471-95.

BERTOLINI, L. (2007). «Evolutionary urban transportation planning? An exploration». In: Frenken, K. (2007). Applied Evolutionary Economics and Economic Geography. Cheltenham: Edward Elgar, 279-310.

Boschma, R. A. and Frenken, K. (2006). «Why is economic geography not an evolutionary science? Towards an evolutionary economic geography». Journal of Economic Geography, 6, 273-302.

- (2007). «Introduction: Applications of evolutionary economic geography». In: FrenKEN, K. (2007): Applied Evolutionary Economics and Economic Geography. Cheltenham: Edward Elgar, 1-26.

- (2011). «The emerging empirics of evolutionary economic geography». Journal of Economic Geography, 11, 295-307.

Boschma, R. A.; Frenken, K. and Lambooy, J. G. (2002). Evolutionaire Economie. Een Inleiding. Bussum: Coutinho.

Boschma, R. A. and Martin, R. (2007). «Editorial: Constructing an evolutionary economic geography». Journal of Economic Geography, 7 (5), 537-48.

BuRghOUWT, G. (2007). Airline network development in Europe and its implications for airport planning. Aldershot: Ashgate.

ButTON, K. and MCDOUgall, G. (2006). «Institutional and structure changes in air navigation service-providing organizations». Journal of Air Transport Management, $12,236-52$.

CAsTells, M. (1996). The Rise of the Network Society. Oxford: Blackwell.

COWAN, R. and JONARD, N. (2003). «The dynamics of collective invention». Journal of Economic Behavior and Organization, 52 (4), 513-32.

De Neufville, R. and Odoni, A. (2003). Airport Systems. Planning, Design and Management. New York: McGraw Hill.

Doganis, R. (2002). Flying off course. The Economics of International Airlines. New York: Routledge.

Dosi, G. and Nelson, R. (1994). "An introduction to evolutionary theories in economics». Journal of Evolutionary Economics, 4, 153-72.

EC (2002). «Directive 2002/30/EC of the European Parliament and the Council of 26 March 2002 on the Establishment of Rules and Procedures with Regard to the Introduction of Noise-Related Operating Restrictions at Community Airport». Brussels: European Commission.

- (2006a). An Action Plan for Airport Capacity, Efficiency and Safety in Europe. Brussels: Commission of the European Communities. 
- (2006b). «Directive 2006/93/EC of the European Parliament and the Council of 12 December 2006 on the Regulation of the Operation of Aeroplanes Covered by Part II, Chapter 3, Volume 1 of Annex 16 to the Convention on International Civil Aviation». 2nd ed. (1988). Brussels: European Commission.

- (2008). «Directive 2008/50/EC of the European Parliament and of the Council of 21 May 2008 on ambient air quality and cleaner air for Europe». Official Journal of the European Communities L152/1. Brussels: European Commission.

EsPey, M. and LÓPEZ, H. (2000). «The impact of airport noise and proximity on residential property value». Growth and Change, 31 (3), 408-19.

EssLetzBiCHLER, J. and RigBY, D. L. (2007). «Exploring evolutionary economic geographies». Journal of Economic Geography, 7 (5), 549-71.

GÁmiR, A.; RAmos, D. (2002). Transporte aéreo y territorio. Barcelona: Ariel.

Gigerenzer, G. and Selten, R. (2002). Bounded Rationality. The Adaptative Toolbox. Cambridge: The MIT Press.

GLÜCKLER, J. (2007). «Economic geography and the evolution of networks». Journal of Economic Geography, 7 (5), 619-34.

Goetz, A. R. and Selten Graham, B. (2004). "Air transport globalization, liberalization and sustainability: Post 2001 policy dynamics in the United States and Europe». Journal of Transport Geography, 12 (4), 265-76.

Graham, B. (1995). Geography and Air Transport. Chichester: John Willey \& Sons.

Graham, B. and GuYer, C. (1999). "Environmental sustainability, airport capacity and European air transport liberalization: Irreconcilable goals?». Journal of Transport Geography, 7 (3), 165-80.

Hodgson, G. M. (2009). "Agency, institutions and Darwinism in evolutionary economic geography». Economic Geography, 85 (2), 167-73.

IATA (2008). IATA Economic Briefing: The Impact of Recession on Air Traffic Volumes. Geneva: IATA.

Karaska, G. and Bramhall, D. (1960). Locational Analysis for Manufacturing: A Selection of Readings. Cambridge: The MIT Press.

Kilduff, M. and TsaI, W. (2003). Social Networks and Organizations. London: Sage.

LEInBACH, T. R. and Bowen, J. T. (2004). "Air cargo services and the electronics industry in Southeast Asia». Journal of Economic Geography, 4 (3), 299-321.

MARTIN, R. (2009). «The Institutional-Evolutionary Interface: Challenges, Contradictions and Conflicts in Economic Geography». In: Round table at the Association of American Geographers Annual Meeting, Las Vegas, 22nd - 27th of April 2009.

Martin, R. and SunleY, P. (2006). «Path dependence and regional economic evolution». Journal of Economic Geography, 6, 395-437.

Nelson, R. (2005). Technology, Institutions and Economic Growth. Cambridge, MA: Harvard University Press.

Nelson, R.; WinTER, S. (1982). Evolutionary Theory of Economic Change. Cambridge, MA: Harvard University Press.

O’Connell, J. F. (2012). Performing Strategic Analysis. Cranfield: Cranfield University.

REYNOLDS-FEIGHAN, A. (1998). "The impact of US airline deregulation on airport traffic patterns». Geographical Analysis, 30 (3), 234-53.

- (2001). "Traffic distribution in low-cost and full-service networks in the US air transportation market». Journal of Air Transport Management, 7 (5), 265-75.

- (2007a). "Competing networks, spatial and industrial concentration in the US airline industry». Spatial Economic Analysis, 2 (3), 237-57. 
- (2007b). "Carrier network structures and the spatial distribution of air traffic in the European air transport market, 1996-2006». Rivista di Politica Economica, I-II, 243-70.

Seguí, J. M. and Martínez, M. R. (2004). Geografía de los transportes. Palma de Mallorca: Universitat de les Illes Balears.

Storper, M. M. (2009). "Regional context and global trade». Economic Geography, $85(1), 1-21$.

STUTZ, F. (1986). «Environmental impacts». In: HANSON, S. (1986). The Geography of Urban Transportation. New York: The Guilford Press, 376-406.

Suau-Sanchez, P. and Burghouwt, G. (2011). "The geography of the Spanish airport system: spatial concentration and deconcentration patterns in seat capacity distribution, 2001-2008». Journal of Transport Geography, 19 (2), 244-54.

Suau-Sanchez, P.; Pallares-Barbera, M. and Paül, V. (2011). "Incorporating annoyance in airport environmental policy. Noise, societal response and community participation». Journal of Transport Geography, 19, 275-84.

Tiffin, J. and Kissling, C. (2007). Transport Communications. Understanding Global Networks Enabling Transport. London: Kogan Page.

Tomkins, J.; Topham, N.; Twomey, J. and Ward, R. (1998). «Noise versus access: The impact of an airport in an urban property market». Urban Studies, 35 (2), 243-58.

Upham, P.; Thomas, C.; Gillingwater, D. and Raper, D. (2003). «Environmental capacity and airport operations. Current issues and future prospects». Journal of Air Transport Management, 9 (3), 15-145.

Witlox, F.; Derudder, B.; Faulconbridge, J. and Beaverstock, J. (2007). «Airline Business Travel Flows in the Global Space Economy. Quantitative and Qualitative Approaches to Analysis». Association of American Geographers Annual Meeting, San Francisco, 17th - 21st April 2007.

Wood, P. (2002). «Services and the 'New Economy': An elaboration». Journal of Economic Geography, 2 (1), 109-14. 